Article

\title{
Implementation of the EU Quality Policy: Case Study, Slovakia
}

\author{
Zuzana Palková ${ }^{1} \mathbb{D}$, Marieta Okenková ${ }^{1}$, Marta Harničárová ${ }^{1, *}$, Jan Valíček ${ }^{1}$, Miroslav Gombár $^{2} \mathbb{D}$, \\ Jakub Dvorský ${ }^{3}$, Mária Behanovská ${ }^{3}$, Monika Slaninová ${ }^{3}$, Monika Reiskupová ${ }^{4}$ and Peter Vnučko ${ }^{5}$
}

1 Department of Electrical Engineering, Automation and Informatics, Faculty of Engineering, Slovak University of Agriculture in Nitra, Tr. A. Hlinku 2, 94976 Nitra, Slovakia; zuzana.palkova@uniag.sk (Z.P.); marietaokenkova@gmail.com (M.O.); jan.valicek@uniag.sk (J.V.)

2 Faculty of Management, University of Prešov in Prešov, Konštantínova 16, 08001 Prešov, Slovakia; miroslav.gombar@unipo.sk

3 Rural Parliament in Slovakia, Kapitulská 13, 97401 Banská Bystrica, Slovakia; jakubdvorsky94@gmail.com (J.D.); maria.behanovska@gmail.com (M.B.); monika.slaninova@gmail.com (M.S.)

4 Municipal Office in Nitra, Štefánikova trieda 60, 95006 Nitra, Slovakia; reiskupova@msunitra.sk

5 Agroinstitut Nitra, Akademická 952/4, 94901 Nitra-Chrenová, Slovakia; peter.vnucko@agroinstitut.sk

* Correspondence: marta.harnicarova@uniag.sk; Tel.: +421-37-641-5782

check for updates

Citation: Palková, Z.; Okenková, M.; Harničárová, M.; Valíček, J.; Gombár, M.; Dvorský, J.; Behanovská, M.;

Slaninová, M.; Reiskupová, M.;

Vnučko, P. Implementation of the EU Quality Policy: Case Study, Slovakia. Sustainability 2021, 13, 7073. https:// doi.org/10.3390/su13137073

Academic Editor: Giuseppe

Antonio Di Vita

Received: 13 May 2021

Accepted: 18 June 2021

Published: 23 June 2021

Publisher's Note: MDPI stays neutral with regard to jurisdictional claims in published maps and institutional affiliations.

Copyright: (c) 2021 by the authors. Licensee MDPI, Basel, Switzerland. This article is an open access article distributed under the terms and conditions of the Creative Commons Attribution (CC BY) license (https:// creativecommons.org/licenses/by/ $4.0 /)$.

\begin{abstract}
The European Union Quality policy promotes original and traditional agricultural and food products of high quality at the EU level. It aims at protecting the names of specific products to promote their unique characteristics, linked to their geographical origin, traditional know-how and local culture. In May 2020, the European Commission launched the EU-wide public consultation on its promotion policy for agricultural and food products to get feedback from citizens and stakeholders on the effectiveness, efficiency and relevance of the current measures, as well as their coherence with EU action in other areas and the added value of this kind of policy being implemented at the EU level. The article is focused on the evaluation effectiveness of the implementation of the EU Quality Policy in Slovakia, covering the territory of the whole country and the aim of this evaluation is to assess the level of awareness in Slovakia regarding the EU Quality policy implementation and the positive and negative experiences with its implementation at the national level. The evaluation period covers all 17 years of its implementation from its introduction in June 2003. Special attention is given to what needs to be done to improve its implementation in Slovakia and to increase the number of Slovak products holding this prestigious label. The main issue that came out of the evaluation process is very poor information on EU Quality Policy implementation in Slovakia. Currently, there is only a website run by the Ministry of Agriculture and Rural Development of the Slovak Republic. There is not much motivation for producers to have an interest in the registration process. Therefore, priority should be given to overcoming this.
\end{abstract}

Keywords: European Union quality policy; rural area; local product; protection; labelling

\section{Introduction}

The EU Quality Policy is the promotion policy for the EU's agricultural and food products. The objective of this policy is to boost the competitiveness and consumption of EU products in and outside the EU [1]. Promotion measures contribute to raising consumer awareness of the merits of the EU's agricultural products and production methods, as well as the awareness and recognition of EU quality and organic farming schemes. The EU promotion policy for agri-food products policy has been in place in its existing form since 2014 [2]. Main activities include participation in trade fairs in and outside the $\mathrm{EU}$, high-level missions with the participation of EU producers, and communication campaigns. The allocated budget has been increasing on an annual basis reaching EUR 200.9 million for 2020. As the EU Quality policy promotes original and traditional agricultural and food products of high quality at the EU level, its aim is to protect the names of 
specific products to promote their unique characteristics, linked to their geographical origin, traditional know-how and local culture [3]. The system was created in response to the growing counterfeiting of products and the misuse of traditional names, which built on the reputation of traditional regional products. The term EU Quality Policy means ensuring the protection of agricultural products and foodstuffs and promoting their sale, and these foodstuffs must meet certain quality parameters that distinguish them from other similar products by their well-defined requirements for their raw material composition and production process. As part of the EU's Quality Policy, the European Union accepts [4], protects, promotes, registers and controls products divided into three categories marked as:

- Protected designation of origin (PDO)

- $\quad$ Protected geographical indication (PGI)

- Traditional specialty guaranteed (TSG).

Geographical indications establish intellectual property rights for specific products, whose qualities are specifically linked to the area of production [5]. Recognised as intellectual property, geographical indications play an increasingly important role in promoting local production and trade [6]. They are also important for emphasising the traditional production process or products.

Developing efficient production processes is a key step in the process of improving product quality by relying on research findings. This is stated by Article 9 of EC Regulation No 2081/92: "the Member State concerned may request the amendment of a specification to take account of developments in scientific and technical knowledge or redefine the geographical area [4]. ISO 8402 (now defunct, and a precursor of ISO 9001:2008 and ISO 9001:2015) defines quality as "quality is the set of properties and characteristics of a product or service that enable it to respond to expressed or explicit consumer needs" [7]. It is a very complex issue to which there is no straightforward answer because product quality often refers to the subjective evaluation of consumers. Therefore, it is necessary to evaluate the product quality based on objective characteristics (like nutritional values or chemical characteristics) that are needed to maintain the well-being of the body and have a positive effect on human health [8-10].

The world population is expected to grow very fast and global demand for food will drastically increase. The impacts of climate change-higher temperatures, extreme weather, increasing levels of carbon dioxide and sea-level rise-are not the only dimensions of concern to European policymakers. There arises a new challenge of promoting the development of rural areas and, especially, finding a new strategy leads to the emergence of prosperous rural communities and is capable of generating public goods for European society as a whole. (EU Commission 2016). Due to the growing pressure on agricultural production, the European Common Agricultural Policy follows the principles of the "Bioeconomy Strategy" (EU Commission 2018) and the "Sustainable Development Goals" (UN 2015) [11-14].

\subsection{Quality Policy Implementation in Slovakia}

The EU Quality Policy was introduced in Slovakia as part of the process of accession to the EU and it was introduced in June 2003, shortly before the entry of Slovakia to the EU in May 2004. It covers the territory of the whole country and as a public scheme is in the responsibility of the Ministry of Agriculture and Rural Development of the Slovak Republic.

The Implementation Instruments in Slovakia

The implementation instruments in Slovakia include the following three pieces of legislation:

1. Law No. 195 from 20th March 2007 amending and adjusting the Law of the National Council of the Slovak Republic 152/1995 on Foodstuffs as amended (Act No 195/2007 Coll. applicable from 1 May 2007) [15].

2. Law No. 469/2003 on Designations of Origin and Geographical Indications of Products and on Amendments to Certain Acts. It was amended 3 times: in March 2007, July 2007 and November 2009 [16]. 
3. Statute of the Commission of the Ministry of Agriculture and Rural Development of the Slovak Republic (hereinafter referred to as "the Ministry") for the assessment of applications for registration of protected designations (protected designation of origin, protected geographical indication, traditional specialty guaranteed) of agricultural products, foodstuffs, spirits and objections to them No. 2735/2013-820. The last time the Statute was updated was in June 2013 [17].

Law No. 152/1995 (on Foodstuffs) lays down the general legal framework for the EU policy implementation in Slovakia. It sets eligibility and requirements for applying for the protection of a designation of origin or geographical indication through the Industrial Property Office of the Slovak Republic. Eligible are associations of producers or processors of agricultural products or foodstuffs or a natural or legal person who, at the time of filing the application, is the only one producing, processing, and preparing a product. Before submitting an application, it is necessary to have prepared a specification of agricultural product or foodstuff, which needs to be professionally assessed and approved by the Ministry. The Ministry is responsible for liaising with the European Commission and for coordination of the whole registration process based on Law No. 469/2003.

There is a different, simpler procedure for application for traditional specialties guaranteed, which goes only through the Ministry. It will publish the application for entry in the register in its Gazette "Journal of Agriculture". A natural person or legal entity may raise objections to an application within two months from the date of its publication in the Ministry's Gazette. If no objections are raised, the application shall be entered in a register kept by the Ministry. The Ministry sends the request for further action to the European Commission. If objections are raised to the application, the Ministry shall assess their admissibility and ensure opposition proceedings. The Ministry shall send the application to the European Commission only after the end of the opposition proceedings. Official control of agricultural products and foodstuffs with a protected designation of origin, protected geographical indication or with the designation of a traditional specialty guaranteed are carried out by the bodies of the State Veterinary and Food Authority.

The Law No. 469/2003 on Designations of Origin and Geographical Indications of Products regulates the conditions for obtaining the right to protection of a designation of origin of a product or geographical area designation of the product, the conditions for the protection of that right and the procedure for obtaining that right for the territory of the Member States of the European Union.

The Statute is an implementation tool established based on the Slovak Law No. 152/1995 Coll. on Foodstuffs and it defines the establishment, status, composition, tasks, rights and obligations of the Commission for the assessment of applications for registration of protected designations products, foodstuffs, spirits and objections to them.

The Commission is an advisory body to the Ministry of Agriculture and Rural Development of the Slovak Republic responsible for the professional assessment of applications for the registration of protected designations of agricultural products and foodstuffs in order to obtain a protected designation of origin, a protected geographical indication and guaranteed traditional specialties. It is also responsible for consideration of objections to changes to applications for registration of protected agricultural designations products, foodstuffs, spirits and in the detection of deficiencies in control. The Chair, Vice-Chair and seven members of the Commission are appointed by the minister of agriculture and rural development and this includes representatives from the food department of the Ministry, Industrial Property Office of the Slovak Republic, State Veterinary and Food Administration of the Slovak Republic, and Research Institute Food and Public Health Office of the Slovak Republic.

\subsection{Current Status of the Policy Measure}

The current number of granted indications is as follows [18]:

- 2 PDO-Protected Designation of Origin

- 10 PGI-Protected Geographical Indication (+1 published +1 applied) 
Geographical Indications (GIs) for spirit drinks and aromatized wines are not part of this evaluation. There is some interest for an easier registration procedure for Traditional specialty guaranteed (TSG) which highlights the traditional aspects such as the way the product is made or its composition, without being linked to a specific geographical area. The name of a product being registered as a TSG protects it against falsification and misuse. There are 7 Slovak products registered at the moment. Four of them have a shared registration with Czechia. The list of Slovak food products as a protected designation of origin and a protected geographical indication (PDO, PGI) according to Title II of Regulation (EU) No 182/2011 of the European Parliament and of the Council 1151/2012 of 21 November 2012 [19] on quality schemes for agricultural products and foodstuffs are listed in Table 1.

Table 1. Slovak food products with PDO and PGI [20].

\begin{tabular}{|c|c|c|c|c|c|}
\hline $\begin{array}{l}\text { Product Name and } \\
\text { Type of Registration }\end{array}$ & Submitted in Slovakia & Applied to the EC & $\begin{array}{l}\text { Publication Date in } \\
\text { Official Journal }\end{array}$ & $\begin{array}{l}\text { Current Situation- } \\
\text { Registration Day in the } \\
\text { Register Kept by } \\
\text { the EC }\end{array}$ & $\begin{array}{l}\text { Name and Place of } \\
\text { Association }\end{array}$ \\
\hline $\begin{array}{c}\text { Skalický trdelník } \\
\text { PGI }\end{array}$ & 2 August 2005 & 18 August 2005 & $\begin{array}{l}21 \text { April } 2007 \\
2007 / C 88 / 02\end{array}$ & $\begin{array}{c}14 \text { December } 2007 \\
\text { PGI-2007/L330/130 }\end{array}$ & $\begin{array}{l}\text { Skalický trdelník } \\
\text { Skalica }\end{array}$ \\
\hline $\begin{array}{l}\text { Slovenská bryndza } \\
\text { PGI }\end{array}$ & 27 April 2004 & 22 September 2004 & $\begin{array}{l}4 \text { October } 2007 \\
2007 / C 323 / 10\end{array}$ & $\begin{array}{c}\text { 16 July } 2008 \\
\text { PGI-2008/L189/19 }\end{array}$ & $\begin{array}{l}\text { Cech bryndziarov } \\
\text { Považská Bystrica }\end{array}$ \\
\hline $\begin{array}{c}\text { Slovenský oštiepok } \\
\text { PGI } \\
\text { (on the basis of Lisabon } \\
\text { Agreement) }\end{array}$ & 22 November 1967 & 30 March 2007 & $\begin{array}{l}19 \text { December } 2007 \\
2007 / \text { C308/10 }\end{array}$ & $\begin{array}{c}25 \text { September } 2008 \\
\text { Agreement with Poland. }\end{array}$ & $\begin{array}{c}\text { Slovenský mliekarenský } \\
\text { zväz } \\
\text { Bratislava }\end{array}$ \\
\hline $\begin{array}{l}\text { Slovenská parenica } \\
\text { PGI }\end{array}$ & 23 June 2005 & 19 July 2005 & $\begin{array}{l}24 \text { October } 2007 \\
2007 / C 249 / 13\end{array}$ & $\begin{array}{c}10 \text { July } 2008 \\
\text { PGI-2008/L183/15 }\end{array}$ & $\begin{array}{l}\text { Cech bryndziarov } \\
\text { Považská Bystrica }\end{array}$ \\
\hline $\begin{array}{l}\text { Oravský korbáčik } \\
\text { PGI }\end{array}$ & & 30 October 2007 & $\begin{array}{l}13 \text { July } 2010 \\
2010 / C 188 / 10\end{array}$ & $\begin{array}{l}11 \text { March } 2011 \\
\text { PGI-2011/L 66/19 }\end{array}$ & $\begin{array}{c}\text { Združenie zázrivských } \\
\text { korbáčikárov } \\
\text { Zázrivá }\end{array}$ \\
\hline $\begin{array}{l}\text { Zázrivský korbáčik } \\
\text { PGI }\end{array}$ & & 30 October 2007 & $\begin{array}{l}13 \text { July } 2010 \\
2010 / C 188 / 11\end{array}$ & $\begin{array}{c}11 \text { March } 2011 \\
\text { PGI-2011/L66/9 }\end{array}$ & $\begin{array}{c}\text { Združenie zázrivských } \\
\text { korbáčikárov } \\
\text { Zázrivá } \\
\end{array}$ \\
\hline $\begin{array}{l}\text { Tekovský salámový syr } \\
\text { PGI }\end{array}$ & & 14 April 2008 & $\begin{array}{c}24 \text { July } 2010 \\
2010 / C 202 / 05\end{array}$ & $\begin{array}{c}11 \text { March } 2011 \\
\text { PGI-2011/ L 66/11 }\end{array}$ & $\begin{array}{c}\text { Levické mliekarne a.s. } \\
\text { Levice }\end{array}$ \\
\hline $\begin{array}{c}\text { Klenovecký syrec } \\
\text { PGI }\end{array}$ & 11 November 2010 & 22 June 2012 & 15 August 2014 & $\begin{array}{c}6 \text { January } 2015 \\
\text { PGI-2015/L8/2 }\end{array}$ & $\begin{array}{l}\text { Cech bryndziarov } \\
\text { Považská Bystrica }\end{array}$ \\
\hline $\begin{array}{l}\text { Zázrivskévojky } \\
\text { PGI }\end{array}$ & 28 October 2011 & 13 August 2012 & 11 April 2014 & $\begin{array}{l}29 \text { August } 2014 \\
\text { PGI-2014/L271/15 }\end{array}$ & $\begin{array}{c}\text { Združenie Zázrivských } \\
\text { korbáčikárov } \\
\text { Zázrivá }\end{array}$ \\
\hline $\begin{array}{l}\text { "Paprika žitava } \\
\text { “/ „Žitavská paprika” } \\
\text { PDO }\end{array}$ & 5 January 2012 & 10 August 2012 & 11 February 2014 & $\begin{array}{c}5 \text { Februry } 2014 \\
\text { PDO-2014/L40/12 }\end{array}$ & $\begin{array}{c}\text { "Capsicum“- Združenie } \\
\text { šl'achtitel'ov, } \\
\text { pestovatel'ov a } \\
\text { spracovatel'ov } \\
\text { koreninovej papriky, } \\
\text { Močenok }\end{array}$ \\
\hline $\begin{array}{c}\text { Levický slad } \\
\text { PGI }\end{array}$ & 18 February 2013 & 20 November 2013 & 28 April 2016 & $\begin{array}{l}27 \text { April } 2016 \\
\text { PGI }\end{array}$ & $\begin{array}{l}\text { OSIVO a.s. } \\
\text { Zvolen }\end{array}$ \\
\hline $\begin{array}{l}\text { Stupavské zelé } \\
\text { PDO }\end{array}$ & 14 June 2013 & 26 October 2015 & 26 October 2015 & $\begin{array}{l}26 \text { April } 2017 \\
\text { PDO }\end{array}$ & $\begin{array}{c}\text { Mestský potravinový } \\
\text { spolok v Stupave } \\
\text { Stupava }\end{array}$ \\
\hline $\begin{array}{l}\text { Liptovské droby } \\
\text { PGI }\end{array}$ & 17 February 2017 & 31 October 2017 & & $\begin{array}{l}\text { Request for registration } \\
\text { presented to the EC on } \\
31 \text { October } 2017\end{array}$ & $\begin{array}{l}\text { Občianske združenie } \\
\text { Liptovské droby }\end{array}$ \\
\hline $\begin{array}{l}\text { Hrušovský lepník } \\
\text { PGI }\end{array}$ & 4 January 2018 & 8 June 2018 & & $\begin{array}{l}\text { Request for registration } \\
\text { presented to the EC on } 8 \\
\text { June } 2008\end{array}$ & $\begin{array}{l}\text { Občianske združenie } \\
\text { Cesta hrušovských } \\
\text { obyčají, Hrušov }\end{array}$ \\
\hline
\end{tabular}

\subsection{Background of the Policy Measure}

Slovakia started with the implementation of the EU Quality Policy together with the new EU Member States much later than the older EU Member States. This is also reflected in the number of food products holding various registrations. 
The comparison with several selected EU countries is provided in Table 2 [21]. It clearly demonstrates the need for increased effort, especially in the area of PDOs, where Slovakia is among the few countries with a very low number of registrations. Much more successful are some other new Members States, such as Croatia with 18 PDOs, Slovenia and Hungary each with 9 PDOs and Poland with 8 PDOs.

Table 2. Food products with PDO, PGI and TSG in selected EU countries.

\begin{tabular}{cccc}
\hline Country & PDO & PGI & TSG \\
\hline Austria & 11 & 7 & 3 \\
Bulgaria & 1 & 2 & 5 \\
Croatia & 18 & 22 & - \\
Cyprus & 2 & 7 & - \\
Czechia & 6 & 25 & 4 \\
France & 105 & 157 & 2 \\
Germany & 17 & 90 & - \\
Greece & 80 & 36 & 1 \\
Hungary & 9 & 22 & 3 \\
Ireland & 4 & 7 & - \\
Italy & 188 & 147 & 5 \\
Poland & 8 & 24 & 10 \\
Romania & 1 & 8 & 1 \\
Slovakia & 2 & 10 & 7 \\
Slovenia & 9 & 13 & 4 \\
\hline
\end{tabular}

Overall, the statistics after more than 17 years of implementation are fairly low, since only 19 products are registered in total and only two in the highest category of PDO. There is a significant space for improvement based on the evaluation of the implementation of the current national instruments and policies in place.

At the beginning of the policy implementation, there was an interest from a group of producers to use these instruments which enables consumers to trust and distinguish quality products and at the same time helping producers to market their products better. In recent years, we can see stagnation, and no product was registered since 2016.

\subsection{National Registrations of Agriculture and Food Products}

Parallel with the EU Quality Policy as many other Member States, the Slovak Republic also uses its own quality labelling-Quality Label "Značka kvality", which represents a guarantee of higher quality agricultural and food products produced in the Slovak Republic from domestic raw materials [22,23]. Except the above mentioned "Značka kvality", several other competing, complementing and differentiating registrations of agricultural and food products with separate and much diverse procedures are available:

1. Quality label SK/Quality label SK GOLD

2. Quality from our Regions

3. Traditional regional product

The National Program is run by the Ministry following the example of other EU Member States. The Food Quality Label with logo SK aims to draw Slovak consumers' attention to quality domestic food and also facilitate foreign food products. It distinguishes other products mainly by higher quality. It was established in 2004 in order to support the consumption of domestic food production and develop a competitive environment after Slovakia's accession to the EU. The aim of the program is to support the traditional domestic production of food, which has an irreplaceable place on the domestic market, because they are a guarantee of "domestic traditional quality" for the consumer. The consumer is becoming more and more demanding and expects not only sufficient quality and a certain "above standard", balanced biological value, attractive packaging, but also attractive appearance and in some cases reduced energy value, all, of course, at a reasonable price. The SK quality mark is a guarantee of the highest quality of agricultural and food product 
and informs the consumer that each product with the brand logo has met the requirements set by the principles of assessment and award, that the manufacturer follows the declared technological process and higher quality parameters, which clearly distinguishes these products from similar products on the market.

"Quality from our Regions" is a national educational project of social responsibility focused on supporting the macroeconomic stability in Slovakia and it is run by a civil society organization called Quality from our Region [24]. The project serves to support the sale of Slovak products and services. It is a social responsibility project based on consumer education through media campaigns and consumer competitions. It explains the impact that a greater preference of the Slovak over the foreign will have, whether in the area of purchasing food, industrial goods or services on our economy. It also points out how such a change in consumer behavior will affect the improvement of the quality of life in Slovakia. The project started as a reaction to insufficient and constantly declining interest of Slovak consumers in domestic products and unfavorable development of the agro-food sector in long term. The main objective is to educate the consumer why it is necessary to buy domestic products, how the economy works and how citizens can participate in their shopping behavior to improve the quality of life of the society in which they live, what impact it has on improving education, health, infrastructure, employment, etc.

The traditional regional product label is awarded by Local Action Groups (LAGs) or Public-Private Partnerships operating on the principles of LEADER [25]. The aim of regional labelling is to promote and provide visibility for individual regions, support local producers and service providers, preserve the values, traditions and uniqueness of the regions and support the use of local resources. It also contributes to the development of sustainable tourism. The system of regional labelling of products and services in Slovakia does not yet have an official representation at the national level. It is open to any region that has clearly defined boundaries. There is a local regional coordinator in each region who is responsible for regional labelling activities and communicates with local producers and service providers. There is an ongoing discussion, which is taking a long time, to design, with uniform minimum criteria, a logo for local products and services to be respected in all regions, while each region can take its own specificities and exceptionality into account in its own regional policies. Another weakness is that there is a lack of continuity due to the changing composition of LAGs.

\subsection{Effectiveness of the Policy Measure}

From Table 3 below, it is evident that at the beginning of the implementation, there was enthusiasm for the EU Quality Policy which has slowly declined over the years as is demonstrated by the number of registered products decreasing to the current very low interest. The last PDO was registered 5 years ago and there are two ongoing registration processes [26].

Table 3. Registration years for products as PDOs and PGIs.

\begin{tabular}{ccc}
\hline Year of Registration & PDOs/PGIs & Number of Registered Products \\
\hline 2007 & PGI & 4 \\
\hline 2010 & PGI & 3 \\
\hline 2014 & PGI & 2 \\
& PDO & 1 \\
\hline 2015 & PDO & 1 \\
\hline 2016 & PGI & 1 \\
\hline Ongoing & PGI & 2 \\
\hline
\end{tabular}


Furthermore, since 2018, there has been no overall progress with registration at all. No further requests from associations are being registered. The initial enthusiasm for the policy implementation in the first years eased over the years. This change can be attributed to many different factors that are points of our research interest and are elaborated further in this article.

\section{Study Area and Research Methodology}

\subsection{Study Area}

This research is carried out within the Horizon 2020 project titled Future-Oriented Collaborative Policy Development for Rural Areas and People (in short, PoliRural) and contributes to its deliverable "Perceived effectiveness of rural interventions in 12 regions: A PoliRural Evaluation" [27]. The evaluation of the implementation of the EU's Quality Policy in Slovakia is directly connected with the top challenges and priority for action is needed in the pilot region of Slovakia. These came out as a result of the needs-gathering exercise within the PoliRural project. There were 6 main priority needs of the region identified in a complex inclusive process involving many relevant stakeholders (beneficiaries and policy actors) at the regional level. This evaluation is related to the following three of them:

I. Need to elaborate a long-term vision for the development and stability of rural areas and agriculture with the aim to restore self-sufficiency, including increasing transparency of direct payments for farmers and rural development program projects and special attention and support given to young, family and small farmers.

II. Need to have sustainable settlements, regions and landscape in the context of climate change, specifically improving access to drinking water, sewerage and clean resources available, sustainable urban development, preventing climate change and protecting terrestrial life.

III. Need to improve quality of public services, for example, create and support teleworking opportunities, improve the mobility possibilities to the main city and the connections between rural and urban areas, increase good medical (primary attention) services and adequate public support for the provision of e-health, edaycare and/or e-learning services, simplify the rules for direct sales of products from farms and restore local market halls and places.

The research presented in this article also feeds into the foresight exercise within which the "Vision for more attractive rural areas in Slovakia" is being developed in a robust, transparent, and inclusive process [28]. Currently, the top main drivers influencing change in rural areas have been identified. Some of them are directly connected with the evaluated policy, e.g., food security, sustainability, job opportunities, diversification of the rural economy, rural tourism, personal health, and civil engagement.

Ultimately, the evaluation is directly connected to supporting the implementation of the vision for the region which is constantly being updated over the duration of the PoliRural project. At this stage, the definition of the vision for the Slovakia region is as follows:

"To increase the attractiveness of the region, well-being of the existing rural population and attract newcomers, while not affecting the symbiosis between city and rural areas, by supporting sustainable and resilient food systems, rural tourism and increasing active and inclusive civil engagement."

By systematically promoting the traditional Slovak agricultural and food products, a significant increase in the attractiveness of rural areas and jobs can be achieved and much-needed further investments can be attracted. The priority of the current Slovak government to increase the self-sufficiency of national agro-food production can be substantially supported by improving and increasing the implementation of the EU Quality Policy at the national level. A major impact on the thriving of rural areas can be envisaged. 


\subsection{Survey Methodology and Data Collection}

The fieldwork focused mainly on a survey accompanied by communication, one workshop with stakeholders from rural areas and consultations with the Ministry of Agriculture and Rural Development of the Slovak Republic, Director General of the Section for Food Industry and Director of the Food Department. The Ministry is the main national body responsible for the implementation of the EU Quality Policy in Slovakia.

The survey was conducted in the Slovak language and required translation of recommended questions prepared by JIIP. Two specific questions related to the EU Quality Policy implementation in Slovakia were added to the end of the questionnaire. In total there were 16 questions, out of which 14 were closed and 2 open. Afterwards, the online survey was created using Google Docs. The survey was officially launched on 23 October 2020 during the online event organized by the Rural Parliament in Slovakia, one of the Slovak PoliRural partners.

Afterwards, the request to fill in the survey was distributed through communications channels of the Slovak pilot team, web pages of the Slovak pilot plus a new dedicated web page to the PoliRural project, social media, mailing lists of partners' organizations, emails of the Slovak pilot panel members. Furthermore, the distribution was increased by e-mail addresses of different organizations and producers either already holding the registration within the EU Quality Policy or with the potential to apply for it. In total, this expanded mailing list covered 147 contacts. Overall, hundreds of emails were distributed with the request to participate in the survey via the link. Kind reminders followed twice towards the end of the survey period.

The online survey was opened for almost a month until 20 November 2020. The initial goal set prior to conducting the survey was to reach a minimum of 30 respondents.

The survey was closed with quite a low return rate of 32 respondents. Even though the initial goal was reached, the expectation of the evaluation team was higher. Given the circumstances of the pandemic situation and the low interest of people, in general, to participate in any surveys, it was considered satisfactory. It was most probably also affected by very low knowledge and understanding of the topic of the EU Quality Policy implementation in Slovakia, as the results of the survey proved later on.

Evaluation of the survey outcomes also proved that those 32 respondents were predominantly from the stakeholders that have direct experience with the EU Quality Policy implementation in Slovakia. There are currently only 19 food products holding one of the three registrations, and the number of respondents reflects this situation.

\subsection{Evaluation Matrix}

The Evaluation Matrix provides guidelines for collecting the information required for the evaluation according to three different criteria: effectiveness, relevance, and coherence.

Section 1 guides the Pilots in collecting general relevant information on the policy measure (The element from which the policy is implemented, which can be a funding program, a tool/instrument, etc.):

(0) Needs

(1) Objectives

(2) Inputs/actions

(3) Outputs

(4) Outcomes

(5) Impacts

Section 2 guides the Pilots in gathering information on the external factors that influence the policy measure.

(a) External influencing factors

(b) External policy factors 
The columns of the evaluation matrix provide the following information:

- Description about the information required

- Tools and references that can be used to get this information (documents, surveys, interviews, focus groups, etc.)

- Suggested questions that can be asked to obtain the required information

Evaluating the policy while using the information collected in Sections 1 and 2, according to the following criteria:

(I) Effectiveness

(II) Relevance

(III) Coherence

The columns of the evaluation matrix provide the following information

- Description of the evaluation criteria

- Tools that can be used to make the evaluation

- Evaluation questions

The interactions between these three sections-evaluation elements, external factors and evaluation criteria-are shown in Figure 1 below and considered in greater detail in the table that follows it.

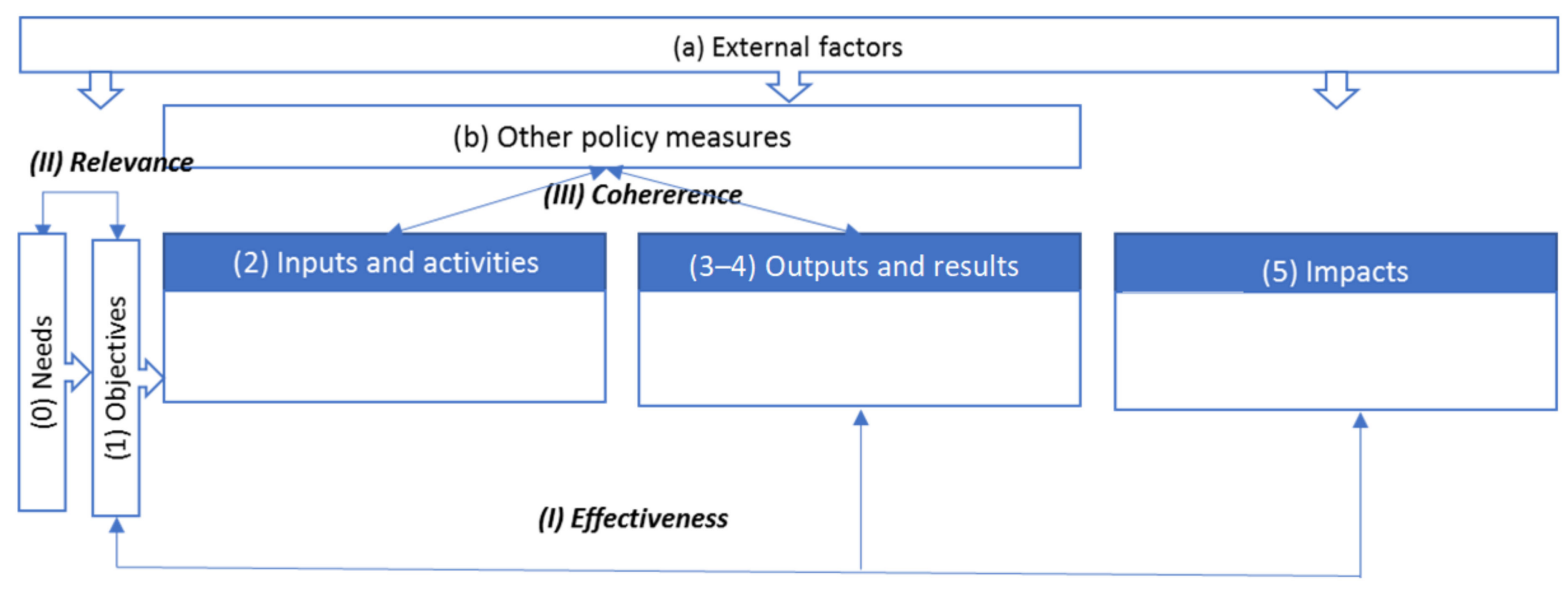

Figure 1. Logframe-graphical illustration.

\section{Results and Discussions}

\subsection{Awareness of the Policy Measure}

According to the results of the survey, the implementation of the EU Quality policy in Slovakia did not achieve its goal of protecting the names of Slovak agricultural products and foodstuffs as is indicated in Figure 2. The majority of respondents thought that it contributed only to a small extent or moderate-low extent and only $10 \%$ to a great extent. 


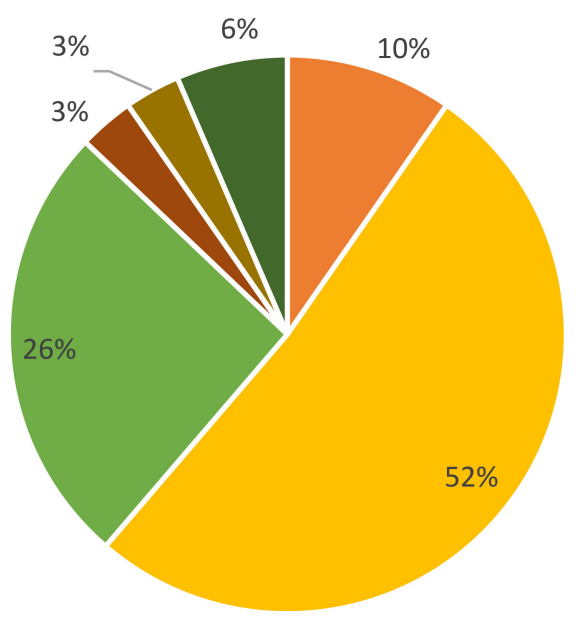

- Not at all

- To a small extent

- To a moderate low extent

- To a moderate high extent

- To a great extent

- Don't know/No Opinion

Figure 2. To what extent does the EU Quality Policy achieve its goals of protecting the names of Slovak foodstuffs?

These results demonstrate that there is very low awareness about the aim of the EU Quality Policy to protect the names of specific products in order to promote their unique characteristics, linked to their geographical origin as well as traditional know-how. Besides the low awareness about the EU Quality Policy, the key obstacles hindering the process are the availability of different other registrations in Slovakia for foodstuffs as specified in 1.3 and a very long time needed for obtaining the registration. The average span is 2-3 years, occasionally even 4 . For the national program, it is a much shorter and more simple procedure.

External factors, such as political, social, economic, environmental, and technological, are not considered by the relevant stakeholders as main contributors to the achievement of the policy objective as is indicated in Figure 3.

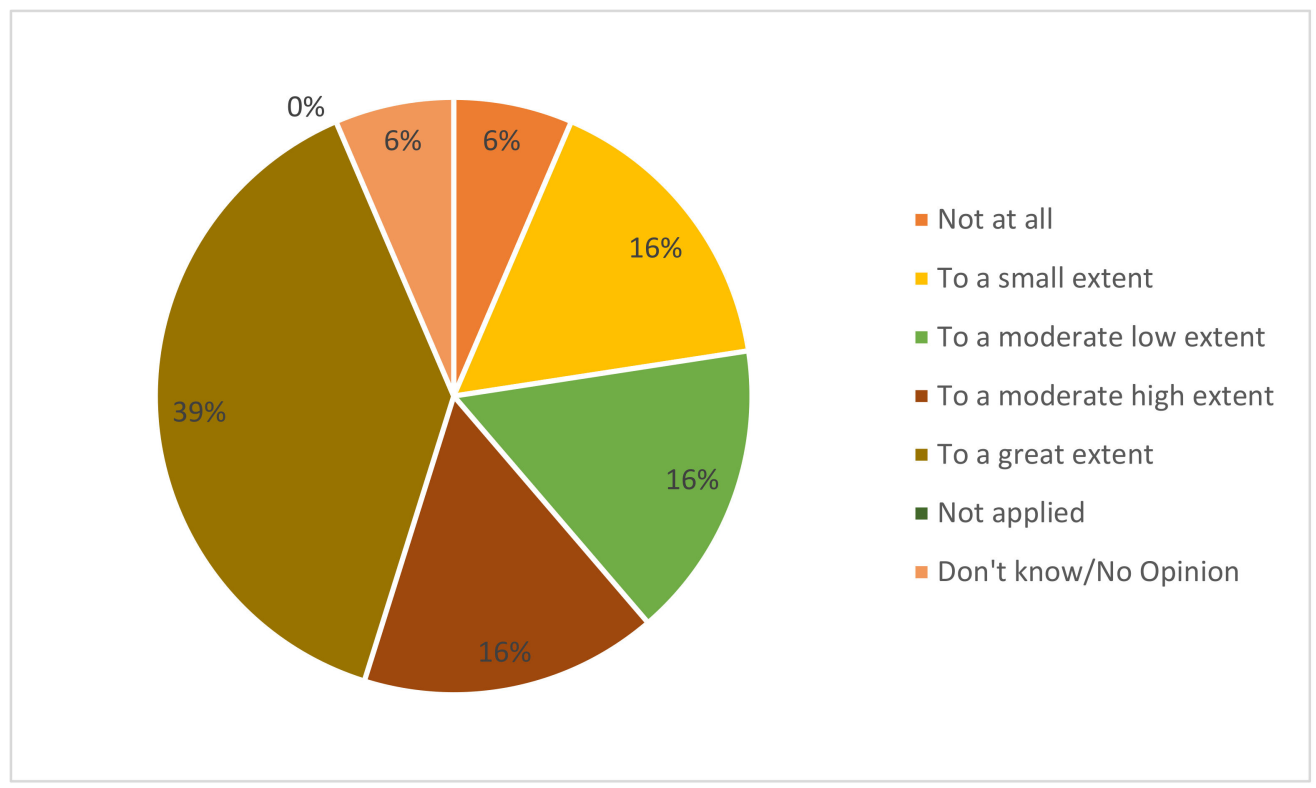

Figure 3. Extent of external factors contributing to the achievement of the EU Quality Policy objectives in Slovakia. 
However, the need for real support benefitting producers with a protected designation over other producers was highlighted. More is expected than just marketing.

Generally, higher support for domestic food producers from the public authorities is highly encouraged. It should move from the position of only control and sanction into exploring the possible ways for more support. There is an expectation for responsible public authorities to have more interest in this policy implementation in Slovakia and to be more proactive for ensuring its more effective implementation. The National Strategy prepared in the broad consultation process with relevant stakeholders could be one of the tools that can kick start the public discussion on this issue and also positively contribute to raising awareness on EU Quality Policy in Slovakia. This strategy can address important issues already identified by stakeholders, such as very strict national legislation for the implementation of the EU legislation and find many others that need to be addressed. The national legislation should reflect the specific interests and requirements of local entrepreneurs and set very simple and clear rules, avoiding complicating their life too much, and instead finding ways how to make them as simple as possible and less demanding. Local conditions and needs need to be reflected when adapting the European legislation to the Slovak perspective and thus avoid any harm or hardship for domestic producers.

Specific attention is required in the area of imports of lower quality food products to Slovakia without certificates and quality control that are requested from the local producers. Traditional food products require specific and targeted support and protection. It should be in the interest of the state to protect and safeguard its traditional products, and the recipes for their production.

\subsection{Relevance of the Policy Measure}

Figure 4 demonstrates a low understanding of the EU Quality Policy in Slovakia since the majority of respondents state that it does not correspond very much to the needs in Slovakia.

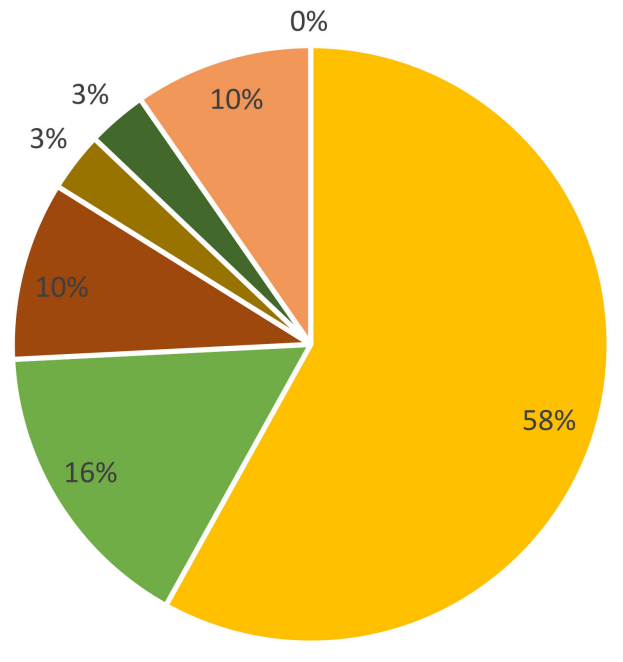

- Not at all

- To a small extent

- To a moderate low extent

- To a moderate high extent

- To a great extent

- Not applied

- Don't know/No Opinion

Figure 4. To what extent does the implementation of the EU Quality Policy correspond to the needs in Slovakia?

Following this, Figure 5 further supports this with a high turnout of respondents not finding this policy relevant for Slovakia. Furthermore, this fact was also supported by answers found in the open questions of the survey, where respondents stated that the main contribution of the EU Quality Policy is to protect traditional products, support the sale of domestic products and reduce imports of low-quality food from the EU. However, the 
respondents almost did not perceive the context that the implementation of the EU Quality Policy can bring for domestic production.

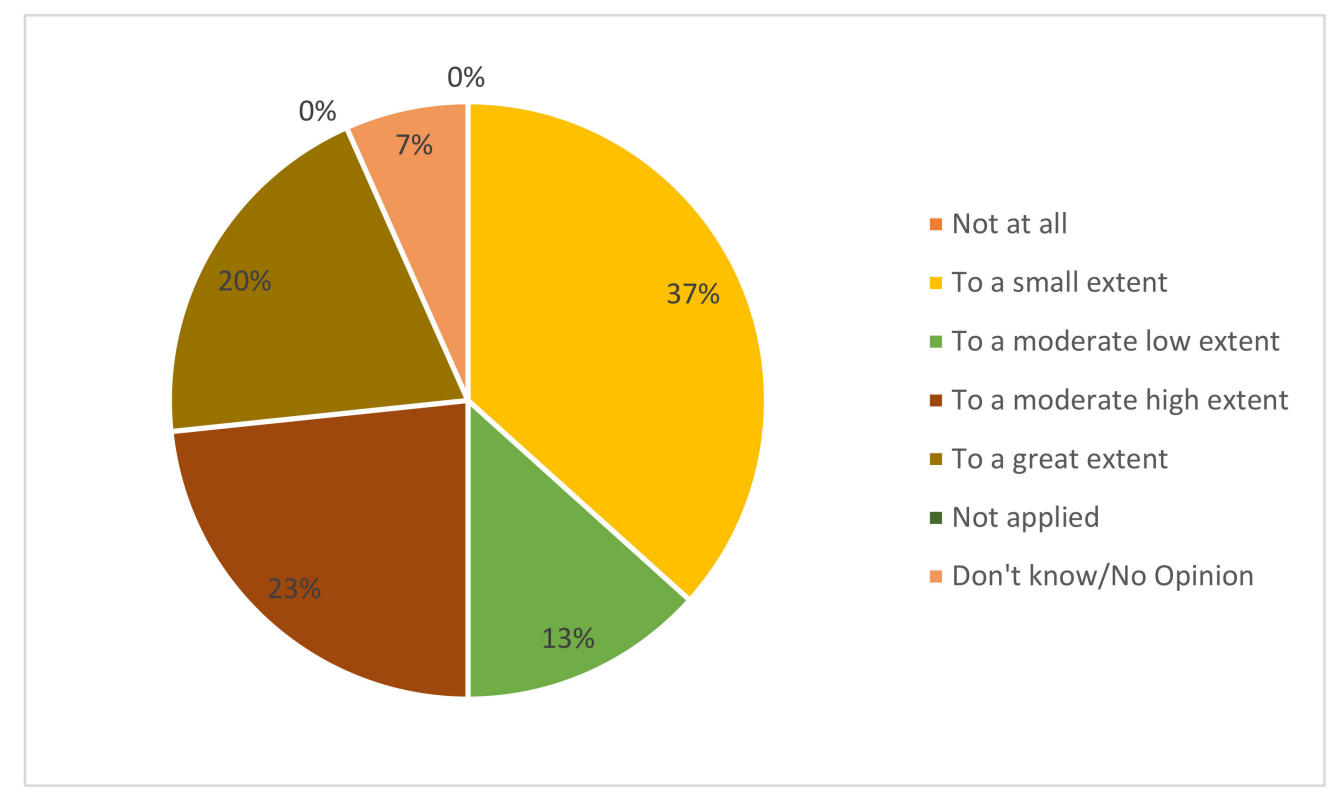

Figure 5. To what extent is the EU Quality Policy relevant for Slovakia?

There is a need to explore the ways how to make the EU Quality Policy more relevant for Slovak producers by better understanding the main constraints.

The implementation should focus more on regular consultations with producers to find out their needs and constraints. An active, inclusive and open network of relevant actors could be one of the solutions.

Furthermore, there is a need for specific work with consumers and the general public on highlighting the importance and contribution of traditional products with traditional recipes and their benefits and quality over other products. Change of consumer behavior in favor of giving preference to traditional Slovak quality products is needed.

When setting the national supporting mechanism for farmers the EU Quality Policy could be considered in order to increase the support for traditional domestic production and improve the position of farmers producing traditional food products. Local production can be stimulated by this.

More targeting of the young generation can generate benefits not only for the EU Quality Policy implementation in Slovakia, but for new entrants coming to live in the countryside also, with the further benefit of keeping the young people already living in the countryside there. It could be one of the options for dealing with aging rural populations. More possibilities and funding targeting young people through all different programs can also contribute to safeguarding traditional agricultural and food production and can bring back life to abandoning rural areas.

Another important target identified is to establish a quality management system by creating quality manuals for food quality. Overall, better targeting on the EU Quality Policy implementation can contribute to the goal of the current government to increase food self-sufficiency in Slovakia. As Figure 6 demonstrates, the EU Quality Policy contributes significantly to rural development in Slovakia. It also shows a low level of knowledge about its contribution. 


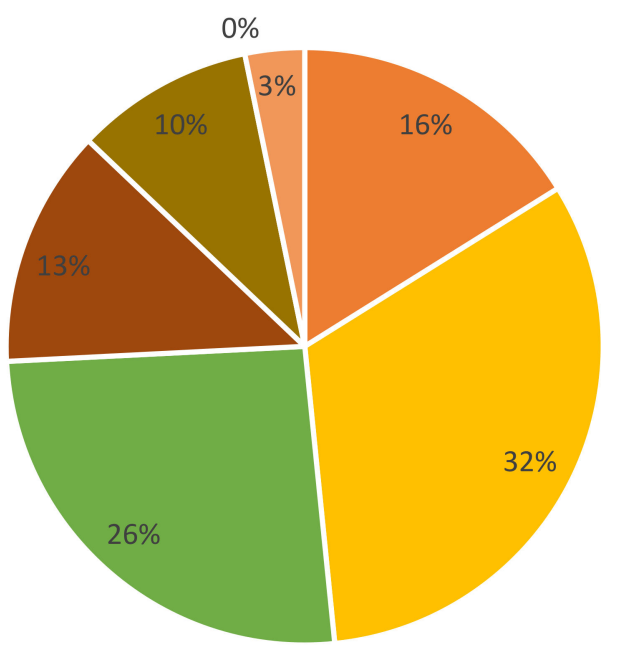

- Not at all

- To a small extent

- To a moderate low extent

- To a moderate high extent

- To a great extent

- Not applied

- Don't know/No Opinion

Figure 6. To what extent does the EU Quality Policy contribute to rural development in Slovakia?

\subsection{Coherence of the Policy Measure}

Figures 7-10 reflect a low level of coherence of the EU Quality Policy implementation with other local and national policies in place with similar objectives as well as with other policies and rural programs.

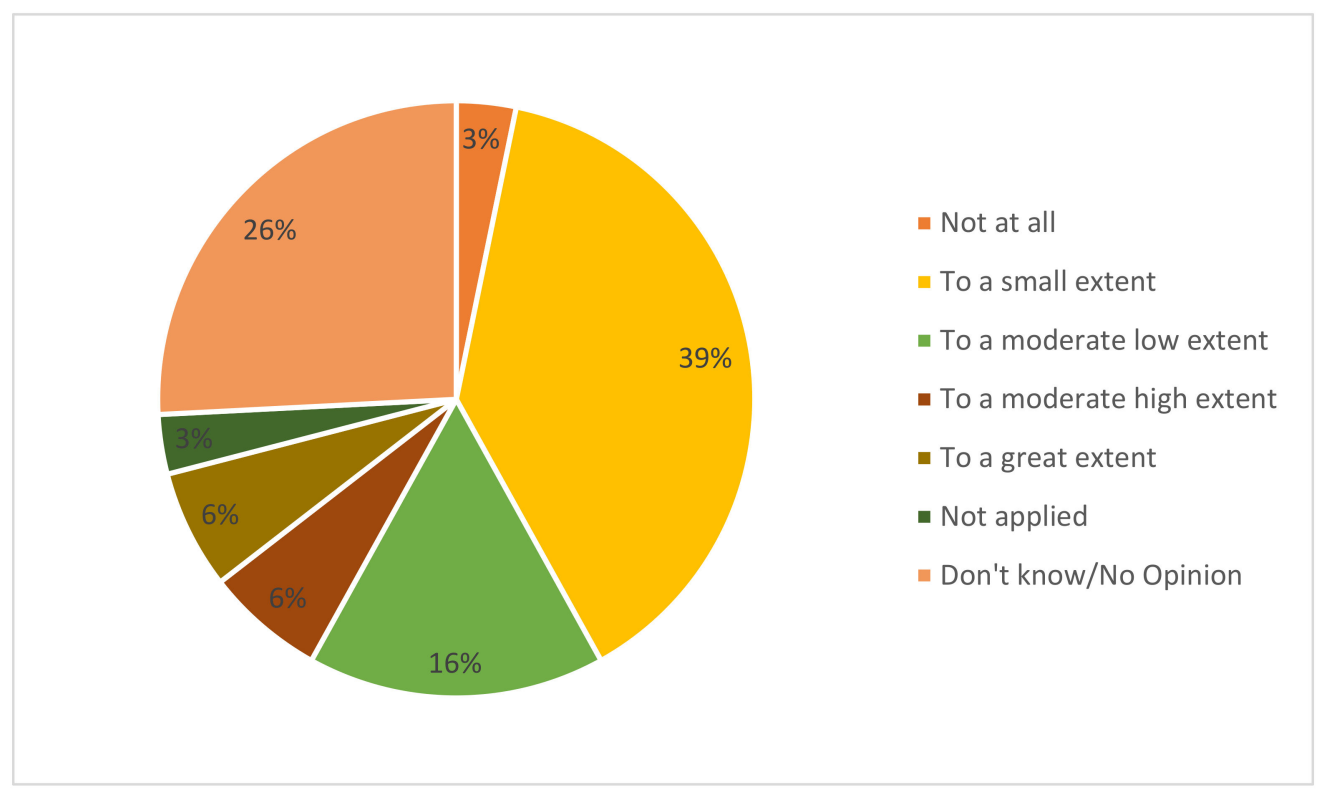

Figure 7. To what extent is the EU Quality Policy coherent in its objectives and actions? 


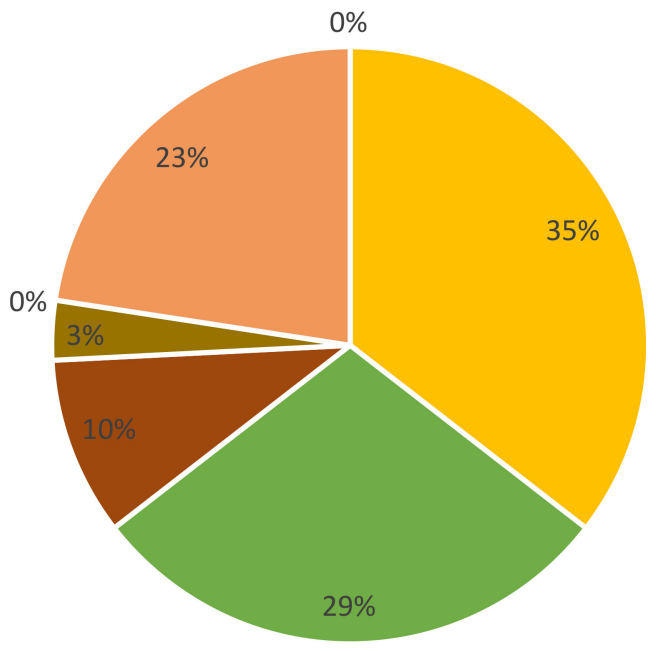

- Not at all

- To a small extent

- To a moderate low extent

- To a moderate high extent

- To a great extent

- Not applied

- Don't know/No Opinion

Figure 8. To what extent is the EU Quality Policy in line with other similar policies in Slovakia?

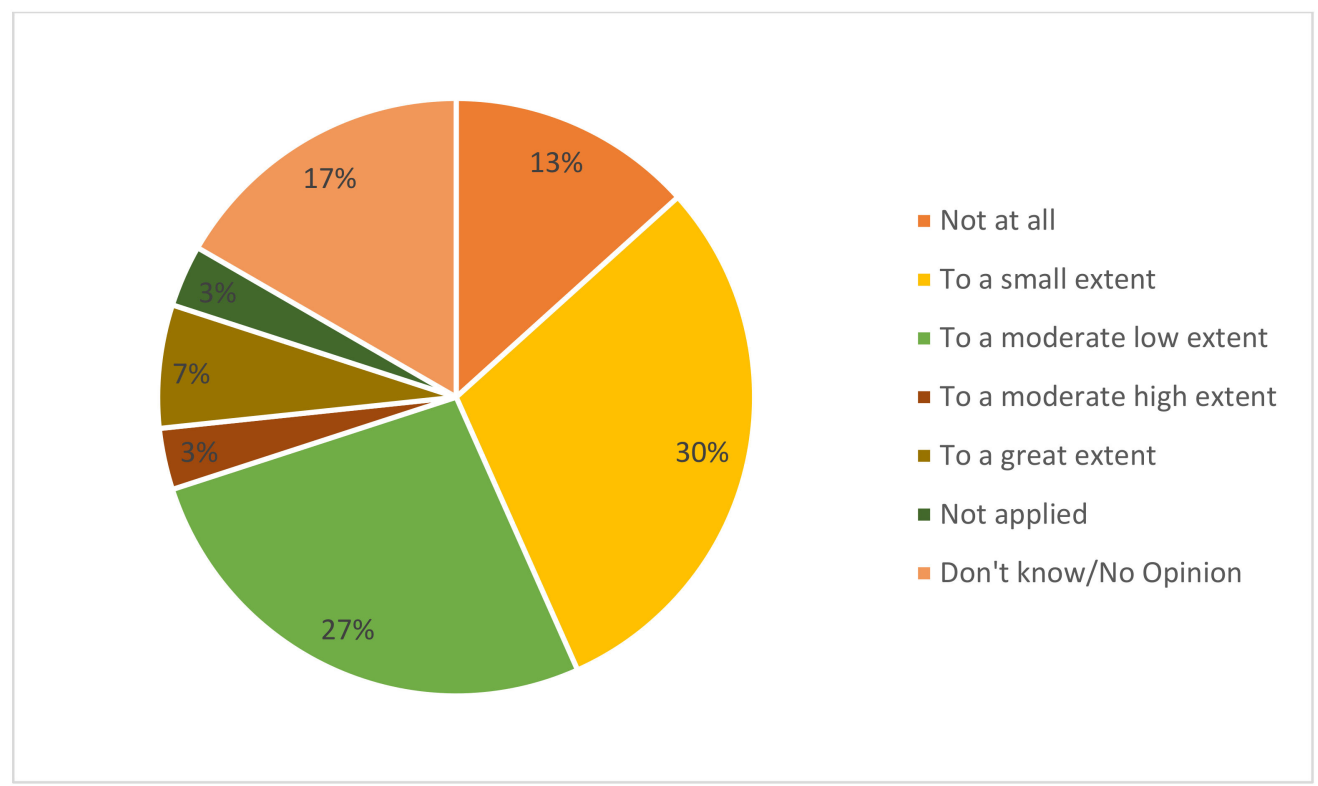

Figure 9. To what extent is the EU Quality Policy part of other rural programs or policies? 


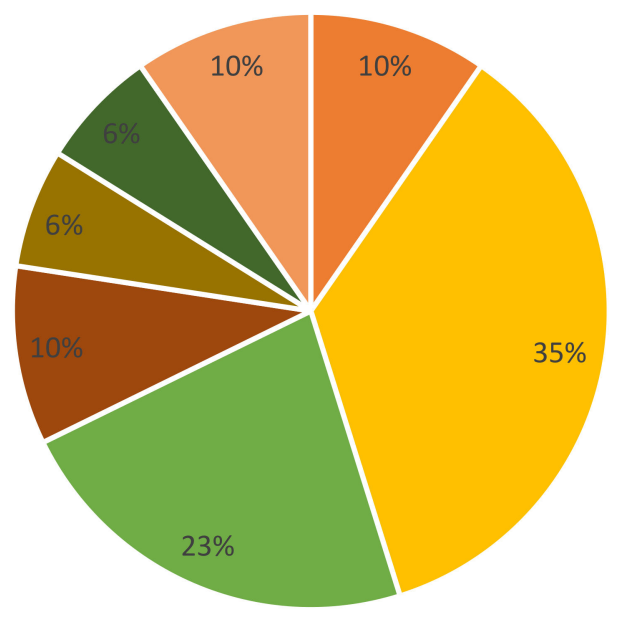

- Not at all

- To a small extent

- To a moderate low extent

- To a moderate high extent

- To a great extent

- Not applied

- Don't know/No Opinion

Figure 10. To what extent is the EU Quality policy linked to other local, regional and national programs and policies?

An example of misunderstanding is the respondents' opinions that it is necessary to comply with local conditions and not to take over nationwide or European regulations in Slovakia, which cannot be applied in practice in our country and harm domestic producers. In this context, it is necessary to increase the awareness (not only) of the rural population and producers about the importance of the EU Quality Policy from the point of view of traditional local production.

In responding to the question of whether the EU Quality Policy is in line with similar policies in Slovakia, or whether it is in line with other EU policies (Figure 9), almost 23\% of respondents stated that they have no knowledge or knowledge of possible contexts.

This can be considered a major shortcoming -if the impact of the EU Quality Policy on the legislative environment for national food quality schemes is not clear, it is not possible to succeed when domestic production competes with imported products.

Significant is the very low impact of the policy implementation on the increase of sales of registered agri-food products, which might be one of the main expectations of the producers (Figure 11). Consequently, this might be the main reason why producer organizations lost interest in recent years in this policy. However, it would be appropriate to carry out a survey as to whether there are obstacles in the implementation process, excessive bureaucracy, and lack of clarity of available information, or simply the lack of interest of potential producers in the quality registration mark. 


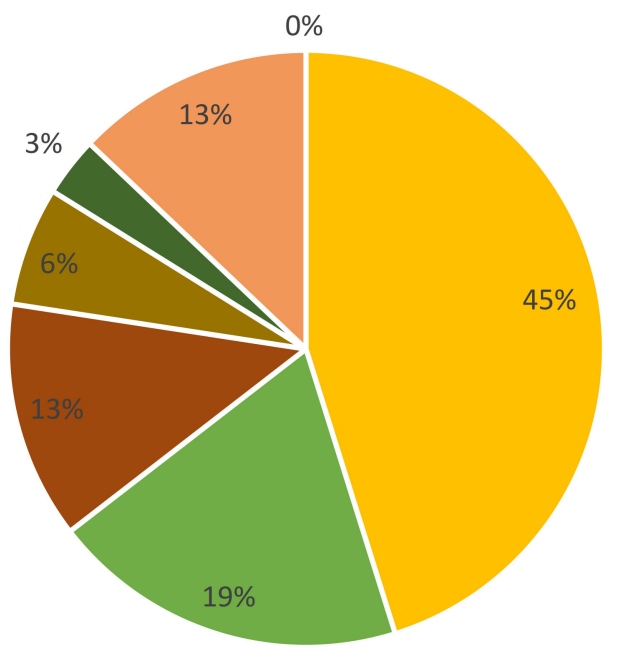

- Not at all

- To a small extent

- To a moderate low extent

- To a moderate high extent

- To a great extent

- Not applied

- Don't know/No Opinion

Figure 11. To what extent has the EU Quality Policy supported sales of registered agro-food products?

It is closely connected to a relatively very low extent of information disseminated about the benefits of the EU Quality policy as shown in Figure 12.

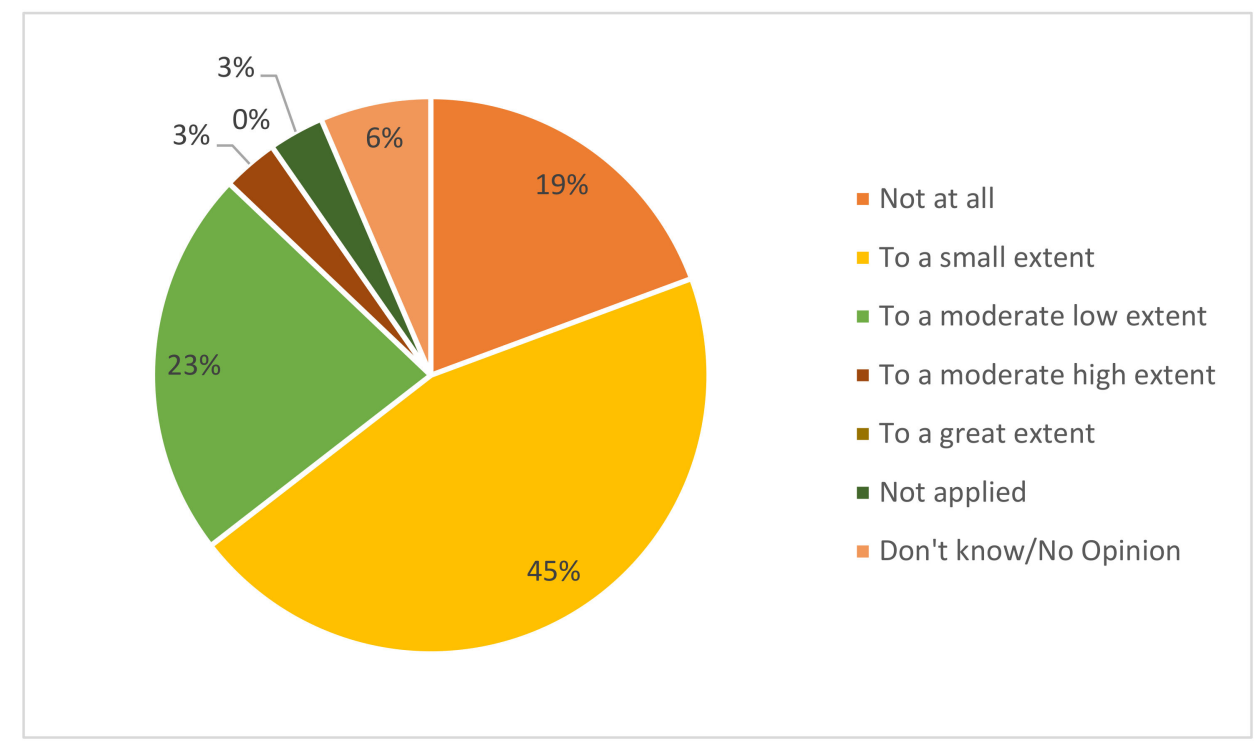

Figure 12. To what extent is the information disseminated about the benefits of the EU Quality Policy in Slovakia?

Almost half of the respondents are convinced that the implementation of the EU Quality Policy has little potential to support the sale of registered agri-food products, as evidenced by the lack of information campaign related to the impact of the EU Quality Policy on domestic production, agritourism and rural development in general.

At the same time, in Figure 13, the representation of $45 \%$ of respondents with a smallextent level of the dissemination of information on the implementation of the EU Quality Policy in Slovakia documents the low level of awareness of relevant interest groups. In this respect, an information campaign focused on examples of good practices, where certified products helped local producers to compete in the competition, would clearly help. 


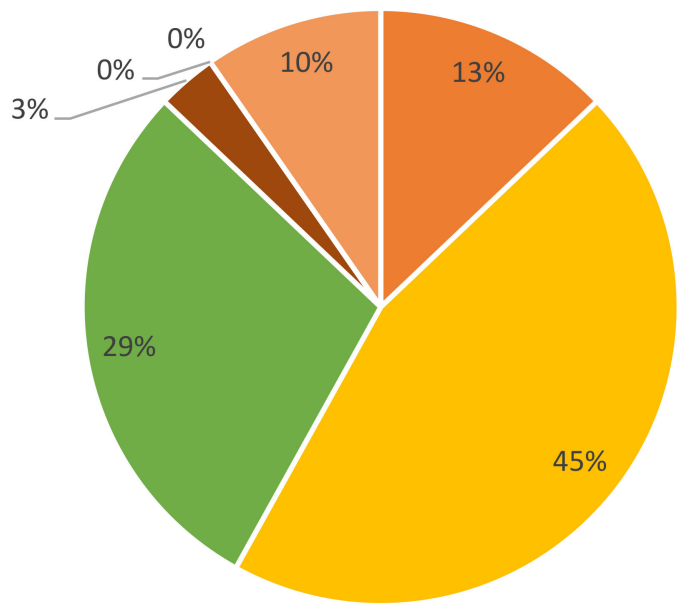

- Not at all

- To a small extent

- To a moderate low extent

- To a moderate high extent

- To a great extent

- Not applied

- Don't know/No Opinion

Figure 13. To what extent is the information available on the method and process of registration?

Figure 13 demonstrates that there is not much information available on the method and process of registration of food products within the EU Quality Policy.

The majority of respondents identified the insufficient promotion of the registered products (Figure 14). Some good marketing strategies are lacking here.

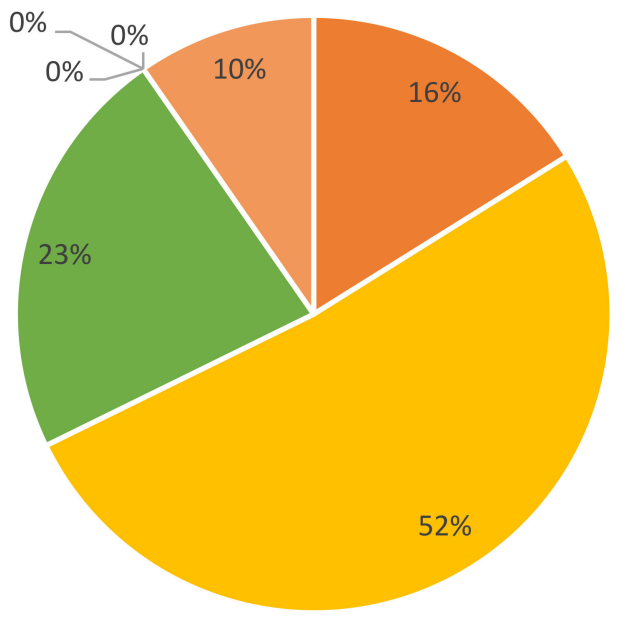

- Not at all

- To a small extent

- To a moderate low extent

- To a moderate high extent

- To a great extent

- Not applied

- Don't know/No Opinion

Figure 14. To what extent are the registered products promoted?

\subsection{Intentions Explained to Policymakers}

During the time of conducting the evaluation, there was an online contact established with the responsible section and department of the Ministry of Agriculture and Rural Development, which was updated on a regular basis about the intention to conduct the survey, the content of the survey and its results as well. They had an opportunity to provide comments to all stages and received the draft survey before its dissemination. Afterwards, there was a special consultation meeting organized with the Director-General of the Food Industry Section and the Director of the Food Department. Due to the limitations caused by COVID-19 restrictions, the meeting was conducted online. It took place on 16 December 
2020 after evaluation of the results of the survey and during the process of formation of conclusions and recommendations for the improvement of the EU Quality Policy implementation in Slovakia. The meeting proved that there is a very good mutual understanding that this policy area is lacking and more needs to be done and additional effort and interventions are needed. The Ministry is in the process of preparing a new marketing strategy supported by additional financial resources that will be directed also to strengthening the EU Quality Policy implementation in Slovakia in near future, starting from the next year. The Ministry also showed a willingness to consult the new draft marketing strategy with the evaluation team after the internal procedures at the end of January 2021. As a basis for the strategy, the Ministry appreciated the availability of the survey results that could be helpful in setting the new policy right according to the needs of the people on the ground. They also showed concern about the low outcome rate of respondents. The Ministry also acknowledges the need to adapt the current national legislation to better reflect the needs of the EU Quality Policy. Another focus area is the dedicated work with the consumers to inform them properly about the differences and value of different registered marks currently available on the domestic market. This requires additional attention and setting the rules more appropriately so that the consumers will not misunderstand the value and meaning of different registrations with special attention given to legally based registrations and voluntary registration awarded by other than state institutions.

\subsection{Statistical Assessment of Obtained Data}

For the purpose of analyses of the research tool, the individual questions items were coded in the following way:

QUEST.ITEM_01
QUEST.ITEM_02
QUEST.ITEM_03
QUEST.ITEM_04
QUEST.ITEM_05
QUEST.ITEM_06
QUEST.ITEM_07
QUEST.ITEM_08
QUEST.ITEM_09
QUEST.ITEM_10
QUEST.ITEM_11
QUEST.ITEM_12
QUEST.ITEM_13
QUEST.ITEM_14
QUEST.ITEM_15
QUEST.ITEM_16

1. To what extent does the EU Quality Policy achieve its aim to protect Slovak agricultural and food products?

2. To what extent do the external factors (political, economic, environmental, social, technological) contribute to achieving the goals of the EU Quality Policy?

3. What are the key success criteria for achieving the goals of the EU Quality Policy in Slovakia?

4. What are the key constraints for the implementation of the EU Quality Policy in Slovakia?

5. To what extent does the implementation of the EU Quality Policy reflect the needs in Slovakia?

6. To what extent did the EU Quality Policy contribute to rural development in Slovakia?

7. To what extent is the EU Quality Policy relevant for Slovakia?

8. To what extent is the EU Quality Policy coherent in its goals and measures?

9. To what extent is the EU Quality Policy in line with other similar policies in Slovakia?

10. To what extent is the EU Quality Policy incorporated into other programs and policies dedicated to rural areas?

11. To what extent is the EU Quality policy connected with other local, regional and national policies and programs?

12. To what extent is the EU Quality Policy in line with other EU policies (Common Agricultural Policy, LEADER, REGIO, CONNECT, etc.)?

13. To what extent has the implementation of the EU Quality Policy supported the sale of registered agro-food products?

14. To what extent is the information on EU Quality Policy in Slovakia spread?

15. To what extent is the availability of information on the registration processes within the EU

Quality Policy?

16. To what extent are registered products within EU Quality Policy promoted?

For the analyses of reliability of the research tool (Table 4), the Cronbach Alpha coefficient was used. Its value had a maximum of 0.835592 . Removing any variable to increase alpha value is not necessary because the change would be negligibly small. Since the value of Cronbach's Alpha exceeds 0.7, it can be concluded that collected data demonstrate reliability and can be used further. 
Table 4. Reliability of the research tool.

\begin{tabular}{|c|c|c|c|c|c|}
\hline \multirow[t]{2}{*}{ Variable } & \multicolumn{5}{|c|}{$\begin{array}{c}\text { Summary for Scale: Mean = 51.8064 Std.Dv. = 15.3328 Valid N:31 (CFA) Cronbach Alpha: } 0.835592 \\
\text { Standardized Alpha: } 0.849214 \text { Average Inter-Item Corr.: } 0.270620\end{array}$} \\
\hline & Mean If Deleted & Var. If Deleted & StDv. If Deleted & Itm-Totl Correl. & Alpha If Deleted \\
\hline Quest. Item_01 & 49.16129 & 206.0708 & 14.35516 & 0.483041 & 0.825421 \\
\hline Quest. Item_02 & 47.90322 & 210.0874 & 14.49439 & 0.339625 & 0.832035 \\
\hline Quest. Item_03 & 49.06452 & 205.0281 & 14.3188 & 0.407325 & 0.828694 \\
\hline Quest. Item_04 & 47.83871 & 216.5224 & 14.7147 & 0.071141 & 0.856749 \\
\hline Quest. Item_05 & 48.74194 & 196.385 & 14.01374 & 0.625384 & 0.816944 \\
\hline Quest. Item_06 & 49 & 202.7742 & 14.23988 & 0.570818 & 0.821378 \\
\hline Quest. Item_07 & 48.32258 & 215.7669 & 14.68901 & 0.220106 & 0.837541 \\
\hline Quest. Item_08 & 47.93548 & 191.0281 & 13.82129 & 0.545462 & 0.820231 \\
\hline Quest. Item_09 & 48.09678 & 197.4422 & 14.05141 & 0.488649 & 0.823999 \\
\hline Quest. Item_10 & 48.48387 & 210.8949 & 14.52222 & 0.221881 & 0.840829 \\
\hline Quest. Item_11 & 48.54839 & 193.8606 & 13.92338 & 0.616042 & 0.816494 \\
\hline Quest. Item_12 & 48 & 198.6452 & 14.09415 & 0.453558 & 0.826272 \\
\hline Quest. Item_13 & 48.3871 & 193.076 & 13.89518 & 0.650784 & 0.814673 \\
\hline Quest. Item_14 & 49.25806 & 196.1915 & 14.00684 & 0.670168 & 0.81525 \\
\hline Quest. Item_15 & 49.09678 & 204.2164 & 14.29043 & 0.464294 & 0.825775 \\
\hline Quest.Item_16 & 49.25806 & 196.4495 & 14.01605 & 0.643532 & 0.81629 \\
\hline
\end{tabular}

The basic indicators of suitability of the use of factor analysis are Kaiser-MayerovaOlkinova (KMO) Statistics and Bartlett's Sphericity test. KMO Statistics present an index that serves to compare the size of experimental correlation coefficients to the size of partial correlation coefficients. If the sum of parties of partial correlation coefficients among all pairs of characters is small compared to the sum of the square of pair correlation coefficients, the KMO statistics are close to 1 . Small KMO statistics indicate that factor analysis of the original characters will not be a good approach because the correlation between pairs is not possible to explain using other characters. According to Keiser-Mayer-Olkin statistics (0.816) as well as Kaiser's definition, the correlation rate is good and the choice of factor analysis based on the research instrument is thus justified. Bartlett's Sphericity Test (Table 5) represents a statistical test of correlation between the original features. It tests the zero hypothesis: H0: "Correlation between characters does not exist", which means that the correlation matrix is a unit matrix. The achieved value of the significance of Bartlett's Spherism Test $p=0.000$ is lower than the level proposed by us at $\alpha=5 \%$. Therefore, the zero hypothesis can be excluded, which was the implementation of the selection correlation matrix with 16 considered variables as a unit matrix. Thus, for the introductory part, it can be stated that factor analysis is suitable for data analysis obtained using a research tool.

Table 5. Value of KMO statistics a Bartlett's Spherism Test, research tool.

\begin{tabular}{llc}
\hline \multicolumn{2}{c}{ Indicator } & Value \\
\hline Kaiser-Meyer-Olkin Measure of Sampling Adequacy. & 0.816 \\
\hline \multirow{3}{*}{ Bartlett's Test of Sphericity } & Approx. chi-Square & 218.810 \\
\cline { 2 - 3 } & $d f$-degrees of freedom & 120 \\
\cline { 2 - 3 } & Sig. & 0.000 \\
\hline
\end{tabular}


For verifying the model on the relationship between variables and their common factors - hidden (latent) variables - we performed a confirmatory factor analysis (using SPSS Amos 21). In the first step, we defined a hypothetical data structure-factors, manifest variables and relationships-between them, based on theoretical constructs and the results of foreign studies. For testing the relevance of the verifying model, we used the following procedures and indexes: chi-square $\chi 2$ (value of chi-square) statistics and the following total match indices with optimal values: (relative chi-square $\chi 2 / d f<2$, RMSEA (root mean square error of approximation) $<0.08$, comparative index TLI $>0.90$, CFI $>0.90$, SRMR (standard root mean square residual) $<0.08$ ) and sub-indexes (the statistical significance of model parameters). CFI (comparative fit index) and TLI (The Tucker-Lewis coefficient) indexes can take values from 0 to 1 , while the values higher than 0.90 indicate the suitability of the applied model. RMSEA index - root from the average square of estimate error (Root Mean Square Error of Approximation)—is less than 0.08 and at the value above 0.1, the model should be rejected. The CHIR-quadrate test takes into account the ratio of chiquadrate and the number of degrees of availability. The ideal chi quadrate approaches from the top of the number of degrees of availability and at multiple models, the more appropriate model is considered the one with the lowest chi-quadrates. In good models, the chi quadrate is statistically insignificant, but this criterion is considered more strictly in the case of larger samples [29].

The model applied within the research part is shown in Figure 15. The model assumes that 13 variables in the form of items of a research tool are explained with three common factors as follows: Efficiency (F1), Relevance (F2) and Cohesion (F3). The first common factor is formed by the first four questionnaire items, the Quest.Item_01 to Quest.Item_04, the second common factor (F2) is formed by Quest.Item_05 to Quest.Item_07, and the third common factor is defined by Quest.Item_08 to Quest.Item_13.

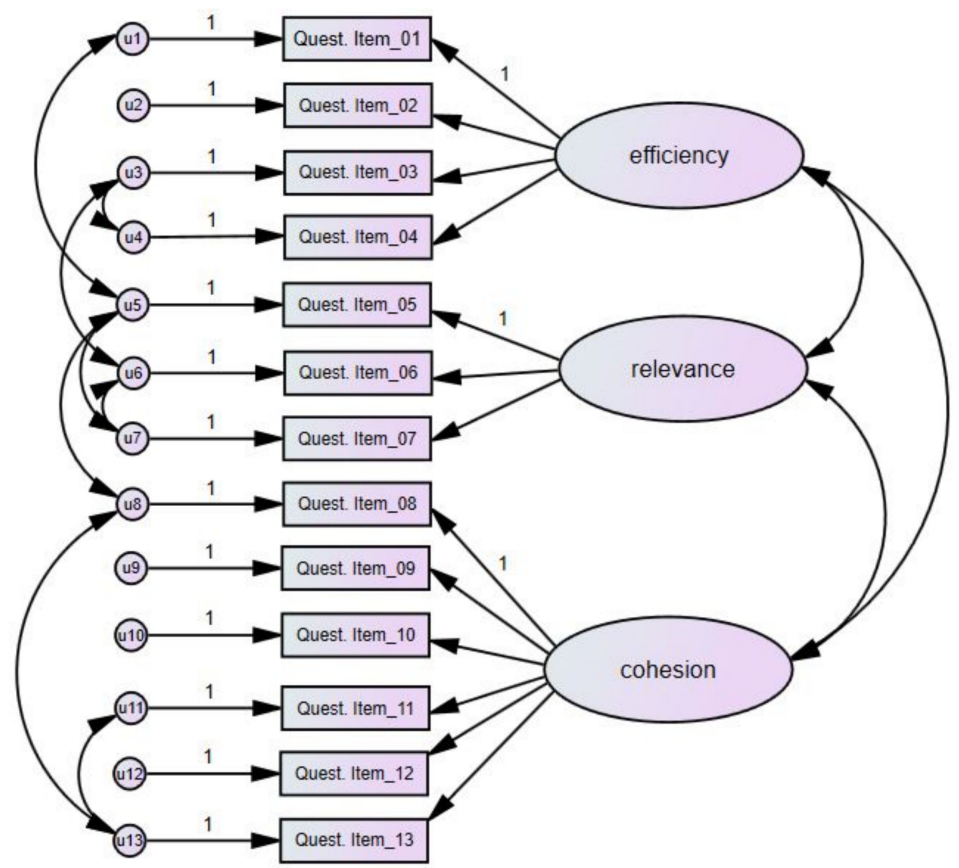

Figure 15. The triple factor model of questionnaire verified by confirmation factor analysis on a sample of Slovak companies.

Compliance Index Values for testing model suitability were as follows: chi square statistics and $\chi 2=60.634, \mathrm{df}=54, p=0.249, \chi 2 / \mathrm{df}=1.1229$, SRMR $=0.046$, RMSEA $=$ $0.064, \mathrm{CMIN} / \mathrm{DF}$ (minimum discrepancy) $=1.123, \mathrm{CFI}=0.933, \mathrm{TLI}=0.903$. Indices show acceptable values and entitle us to state that the hypothetical model presents a good degree of conformity with real data and is applicable in such form. For any comparison 
of models, the value of information criteria is: AIC (The Akaike information criterion) $=$ 134.634 and BIC (The Bayes information criterion) $=187.692$. The 3-Factor Model EPOCHs are analyzed in the merged files and files according to gender and age were analyzed also in terms of individual parameters. Standardized regression scales were statistically significant $(p<0.05)$ at Quest.Item_01 $(p=0.003)$ Quest.Item_05 $(p=0.003)$, Quest.Item_06 $(p=0.003)$, Quest.Item_08 ( $p=0.002)$, Quest.Item_09 $(p=0.001)$, Quest.Item_11 $(p=0.017)$ and Quest.Item_12 ( $p=0.002)$, with values higher than 0.50 . The values of standardized regression scales and robust standardized measurement errors in the merged file are given in the Table 6.

Table 6. Regression scales and standardized model errors.

\begin{tabular}{lccccccc}
\hline & Relationship & & Estimate & Std.Estimate & S.E. & C.R. & $p$ \\
\hline Quest.Item_01 & $<-$ & efficiency & 1 & 0.528 & 0.214 & 2.884 & $0.003 *$ \\
Quest.Item_02 & $<-$ & efficiency & 1.296 & 0.628 & 0.801 & 1.617 & 0.106 \\
Quest.Item_03 & $<-$ & efficiency & 0.871 & 0.392 & 0.635 & 1.372 & 0.17 \\
Quest.Item_04 & $<-$ & efficiency & -0.802 & -0.245 & 0.865 & -0.927 & 0.354 \\
Quest.Item_05 & $<-$ & relevance & 1 & 0.573 & 0.219 & 2.997 & $0.003 *$ \\
Quest.Item_06 & $<-$ & relevance & 0.635 & 0.599 & 0.268 & 2.371 & $0.018^{*}$ \\
Quest.Item_07 & $<-$ & relevance & 0.15 & 0.09 & 0.259 & 0.581 & 0.562 \\
Quest.Item_08 & $<-$ & cohesion & 1 & 0.783 & 0.242 & 3.675 & $0.002 *$ \\
Quest.Item_09 & $<-$ & cohesion & 0.856 & 0.727 & 0.239 & 3.585 & $0.001 *$ \\
Quest.Item_10 & $<-$ & cohesion & 0.349 & 0.288 & 0.227 & 1.537 & 0.124 \\
Quest.Item_11 & $<-$ & cohesion & 0.504 & 0.563 & 0.211 & 2.393 & $0.017 *$ \\
Quest.Item_12 & $<-$ & cohesion & 0.733 & 0.611 & 0.237 & 3.099 & $0.002 *$ \\
Quest.Item_13 & $<-$ & cohesion & 0.337 & 0.312 & 0.185 & 1.817 \\
\hline
\end{tabular}

*—signifikantné na hladine významnosti $\alpha=5 \%$.

Correlations among the scales highlighted the significant relationships between all dimensions (Table 7). We assessed the correlation values by key: $\mathrm{R} \geq 0.5=$ high, $\mathrm{R} \geq 0.3=$ medium $/$ mild, $R \geq 0.1=$ low, $R \geq 0=$ negligible [30]. We found the strongest relationships between latent relevance and cohesion variables, between efficiency and relevance as well as between latent variables $u 11$ and $u 13$ (0.856, 0.808 and 0.655$)$. Medium-strong relationships in the sense of the Cohen scale were shown between latent variables $u 1$ and $u 5(0.489)$, between $u 3$ and $u 4(0.489)$ between $u 8$ and $u 13(0.488)$ and negative correlation between latent variables $u 5$ and $u 8(-0.395)$. Latent variables $u 1$ to $u 13$ are defined in the context of the Questionnaire's questions Q1 to Q13.

Table 7. Correlations of unnoticed, exogenous model variables.

\begin{tabular}{cccccccc}
\hline & Relationship & & Estimate-Covariation & Estimate-Correlation & S.E. & C.R. & $p$ \\
\hline relevance & $<->$ & cohesion & 1.677 & 0.856 & 0.589 & 2.845 & $0.004^{*}$ \\
efficiency & $<->$ & relevance & 0.533 & 0.808 & 0.411 & 1.298 & $0.024^{*}$ \\
efficiency & $<->$ & cohesion & 0.228 & 0.188 & 0.331 & 0.687 & $0.042^{*}$ \\
u1 & $<->$ & $u 5$ & 0.743 & 0.489 & 0.389 & 1.91 & $0.046^{*}$ \\
$u 3$ & $<->$ & $u 4$ & 1.738 & 0.486 & 0.738 & 2.355 & $0.019^{*}$ \\
$u 3$ & $<->$ & $u 6$ & 0.446 & 0.227 & 0.364 & 1.226 & $0.022^{*}$ \\
$u 5$ & $<->$ & $u 7$ & 0.223 & 0.119 & 0.263 & 0.849 & $0.046^{*}$ \\
$u 5$ & $<->$ & $u 8$ & -0.65 & -0.395 & 0.325 & -2.003 & $0.045^{*}$ \\
$u 6$ & $<->$ & $u 7$ & 0.438 & 0.23 & 0.331 & 1.323 & $0.016^{*}$ \\
$u 11$ & $<->$ & $u 13$ & 1.729 & 0.655 & 0.526 & 3.285 & $0.001 *$ \\
$u 8$ & $<->$ & $u 13$ & 1.06 & 0.488 & 0.437 & 2.427 & $0.015^{*}$ \\
\hline
\end{tabular}

*-significants at the importance level $\alpha=5 \%$, where S.E.-standard error of the regression weight estimate, C.R.-regression weight estimate and $p$-Probability level. 


\subsection{Recommendations}

To break the stagnation in registration over the last few years, the set of eight main recommendations came out of the evaluation process. These can significantly contribute to improving the implementation of the EU Quality Policy in Slovakia in coming years:

1. Increased effort in the area of promoting the EU Quality Policy is needed in Slovakia. This requires a more proactive attitude of the responsible MofAR of the Slovak Republic by kick-starting the drafting process of a National Marketing Strategy prepared in a broad consultation process with relevant stakeholders and actors. This could be one of the tools to start the public discussion on this issue and also positively contribute to raising awareness on EU Quality Policy in Slovakia. This strategy can address important issues already identified by stakeholders, such as very strict national legislation for the implementation of the EU legislation, and find many others that need to be addressed. The national legislation should reflect the specific interests and requirements of local entrepreneurs and set very simple and clear rules, avoiding complicating their life too much, but instead finding ways to make them as simple as possible and less demanding. Local conditions and needs need to be reflected when adapting the European legislation to the Slovak perspective and thus avoid any harm or hardship for domestic producers. It should include regular information campaigns on the explaining the EU Quality Policy and difference from other similar policies, organizing regular events focused on the presentation of the aims of the EU Quality Policy and the contribution it can have to protecting, safeguarding and promoting the production of local domestic products not only on the national but also on European and global levels. Successful implementation of the marketing strategy requires the allocation of adequate financial resources to support it. The financial contribution should be continuous and not a single case or option. This could be one of the factors positively influencing the interest and motivation of producers to get involved and start the registration process.

2. There is a need to support and help producers to market their protected products better. In order to better promote the products already holding the registration requires the involvement of all actors, at all production levels from farm to table. A useful tool could be the common crafting of the National Plan for the promotion of the products holding the registrations. The registered products should be used also officially by public institutions and authorities as part of national honour and pride. This could generate more interest from producers and their organizations to apply for the various registrations.

3. Protected products require specific recognition and work with consumers to inform them that these are quality products that they can trust and learn to distinguish them from others. Special promotion campaigns dedicated to PDOs, PGIs and TSGs are necessary to be introduced. They can be prepared and implemented in joint collaboration with the Ministry and associations involved. Promotion campaigns should include information on the quality of raw material and ingredients used for the production of registered foodstuffs to distinguish them from the others and the prices the consumers will have to pay for them, which are usually higher than other similar products. The positive impact on human health and the environment should be highlighted. The closer the food products are produced to the consumer, the lower is the impact on the environment since transportation and handling are limited. Slovak consumers need to be better informed to make the right shopping choices and establish regular shopping habits. The EU Quality Policy creates a legal framework for support and protection of original and traditional food products of quality and at the same time safeguarding traditions and culture of the given region. It can also have a positive effect on stimulating the local and regional agricultural and food production. These products are more attractive and interesting for consumers and provide a higher guarantee of food safety since they are controlled more deeply by authorized 
public control authorities. This creates an added value for these agricultural and food products.

4. Special focus needs to be dedicated to the PDOs since there are only two at the moment holding the registration, which is quite low in comparison with neighboring and other EU countries. Both of them were registered some time ago, the first one in 2014 and the second one in 2017. PDOs contribute the most to local production since there is a close production cycle in a certain territory.

5. Establish communication and regular contact with other EU countries in order to exchange experiences, views and obstacles hindering the implementation of the EU Quality Policy and finding jointly ways how to overcome them.

6. Establish a regular channel of communication with all relevant stakeholders and actors via a specific platform or network, which is open, active and effective.

7. Explore the possible ways of reducing the time needed for obtaining the registration since the current span of 2-3 years, sometimes even 4 years, which might significantly contribute to decreasing the attractiveness of the EU Quality Policy for producers and their associations.

8. Generally, higher support of domestic food producers from the public authorities is highly encouraged. It should move from the position of only control and sanction into exploring the possible ways for more support.

Producers and their organizations have greater expectations for support from the national responsible authorities, not only in terms of marketing, but real support of local production. One of the options could be to find a way within different national support schemes of how to prioritize and/or favour other producers that are dedicated to local production with higher added value such as the registered products within the EU Quality Policy. Positive effects will also be seen on local employment and the economy, thus contributing to the thriving of rural areas. Special focus should be given in this regard to the young generation in order to make this attractive for them and thus ensure generational exchange in agriculture and food production sectors and keep the rural areas lively. Small and medium-sized producers would also benefit, along with the development of rural tourism and agrotourism.

\section{Conclusions}

The research was implemented in the specific field of economy, which is mainly focused on the production of agricultural and food products with the aim to promote their unique characteristics connected to their geographical origin and traditions. Due to the fact that, since 2016, no new agro-food product was registered and after 17 years of the EU Quality Policy implementation in Slovakia there are only 19 products currently holding the registration, the research sample was considerably limited. To this, other factors were also attributed, such as many different local and national registrations available to producers and a low level of awareness in general about the EU Quality Policy. These factors significantly inhibited us in obtaining a larger sample of respondents. The initial target of the research team to achieve at least 30 respondents was achieved. The choice of respondents was implemented by quota selection based on availability. Despite the relatively small sample of relevant entities, the results of the assumptions of the use of factor analysis, namely KMO, which achieved a value of 0.816 and the value of Bartlett's Spherism $(p=0.000)$, points to the fact that the results of the analysis can be considered relevant. This conclusion was subsequently supported by the indicators of CFA (confirmation factor analysis) used.

Overall, the implementation of the EU Quality Policy in Slovakia was designed and implemented appropriately and coherently since its introduction in 2003. The national legal framework allowing the implementation of the EU Quality Policy in Slovakia is appropriate and in line with the EU legislation. In this regard, additional attention needs to be given to other voluntary labels being used on the national level especially in terms of 
informing the consumers on differences between them. This would be highly beneficial for improving the EU Quality Policy implementation in Slovakia.

Some positive results have been achieved over the last 17 years, but there is still a lot of space for improvement of the EU Quality Policy implementation in Slovakia and increasing its effectiveness. This measure requires more attention from the responsible Ministry, relevant associations, retailers, and consumers. Therefore, the decision needs to be taken at the national level if more effort and resources shall be put into this measure or not, depending on the available capacities of the relevant public authorities and the interest of groups of producers.

The main issue that came out of the evaluation process is very poor information on the EU Quality Policy implementation process in Slovakia. Currently, there is only a website run by the Ministry of Agriculture and Rural Development of the Slovak Republic (MofA\&RD of SR). Furthermore, there is not much motivation for producers to have an interest in the registration process. Therefore, priority should be given to overcoming this.

Author Contributions: Conceptualization, M.O. and M.B.; methodology, Z.P.; software, P.V.; validation, Z.P., M.O. and M.S.; formal analysis, J.D.; investigation, Z.P.; resources, M.H.; data curation, J.V and M.G.; writing—original draft preparation, Z.P.; writing—review and editing, J.V.; visualization, M.H.; supervision, Z.P.; project administration, M.R.; funding acquisition, Z.P. All authors have read and agreed to the published version of the manuscript.

Funding: This research has received funding from the European Union's Horizon 2020 research and innovation program under grant agreement $\mathrm{N}^{\mathrm{o}} 818496$.

Institutional Review Board Statement: Not applicable.

Informed Consent Statement: Not applicable.

Data Availability Statement: The data presented in this study are available on request from the corresponding author after obtaining permission of authorized person.

Conflicts of Interest: The authors declare no conflict of interest.

\section{References}

1. EC. European Commission Seeks Feedback on Promotion Policy for Agri-Food Products; European Commission (EC): Brussels, Belgium, 2020.

2. Clark, J.K.; Sharp, J.S.; Dugan, K.L. The agrifood system policy agenda and research domain. J. Rural Stud. 2015, 42, 112-122. [CrossRef]

3. Becker, T.C.; Staus, A. European food quality policy: The importance of geographical indications, organic certification and food quality insurance schemes in European countries. J. Int. Trade Law Policy 2009, 10, 111-130.

4. European Council Regulation. EEC No 2081/92 of 14 July 1992 on the protection of geographical indications and designations of origin for agricultural products and foodstuffs. Off. J. Eur. Union L 1992, 208, 1-8.

5. Moschini, G.; Menapace, L.; Pick, D. Geographical indications and the competitive provision of quality in agricultural markets. Am. J. Agric. Econ. 2008, 90, 794-812. [CrossRef]

6. Belletti, G.; Marescotti, A.; Touzard, J.M. Geographical indications, public goods, and sustainable development: The roles of actors' strategies and public policies. World Dev. 2017, 98, 45-57. [CrossRef]

7. BSI. Quality Management and Quality Assurance \pm Vocabulary; BS EN ISO 8402 (formerly BS 4778: Part 1, 1987/ISO 8402, 1986); British Standards Institution: London, UK, 1995.

8. Casabianca, F.; Matassino, D. Local resources and typical animal products. In Livestock Farming Systems. Product Quality Based on Local Resources Leading to Improved Sustainability, 1st ed.; Rubino, R., Sepe, L., Dimitriadou, A., Gibon, A., Eds.; Wageningen Academic Publishers: Wageningen, The Netherlands, 2006; pp. 9-26.

9. Nardone, A.; Valfrè, F. Effects of changing production methods on quality of meat, milk and eggs. In Proceedings of the 8th World Conference on Animal Production, Special Symposium and Plenary Sessions, Seoul, Korea, 28 June-4 July 1998; pp. $246-264$.

10. Tornberg, E. Biophysical aspects of meat tenderness. Meat Sci. 1996, 43, 175-191. [CrossRef]

11. Arfini, F.; Bellassen, V. Sustainability of European Food Quality Schemes. In Multi-Performance, Structure, and Governance of PDO, PGI, and Organic Agri-Food Systems; Springer International Publishing: Cham, Switzerland, 2019; 567p.

12. UN. Transforming our World: The 2030 Agenda for Sustainable Development. 2015. Available online: https:// sustainabledevelopment.un.org/content/documents/21252030\%20Agenda\%20for\%20Sustainable\%20Development $\% 20$ web.pdf (accessed on 16 April 2021).

13. Updated Bioeconomy Stratedy. In A Sustainable Bio-Economy for Europe: Strengthening the Connection between Economy, Society and the Environment; European Commsions: Brussels, Belgium, 2018; ISBN 978-92-79-94145-0. 
14. EU Commission. Cork 2.0 Declaration, 2016. A Better Life in Rural Areas. 2016. Available online: https://www.arc2020.eu/wpcontent/uploads/2016/09/cork-declaration-2-0_en.pdf (accessed on 16 April 2021).

15. Act of the National Council of the Slovak Republic No. 152/1995 Coll., as Amended. Act No. 355/2007 Coll., as Amended. Available online: https://www.unms.sk/swift_data/source/aj_verzia/testing/264_EN_07_08_09.pdf (accessed on 31. March 2021).

16. Act of the National Council of the Slovak Republic No. 469/2003 Coll. on Designations of Origin for Products and Geographical Indications for Products and on Amendment of Some Acts. Available online: https://www.indprop.gov.sk/swift_data/source/ pdf/legislation/pravo_03469.pdf (accessed on 30 March 2021).

17. Statute of the Commission of the Ministry of Agriculture and Rural Development of the Slovak Republic (Herein after Referred as "the Ministry") for the Assessment of Applications for Registration of Protected Designations (Pro- tected Designation of Origin, Protected Geographical Indication, Traditional Specialty Guaranteed) of Agricultural Products, Foodstuffs, Spirits and Objections to Them No. 2735/2013-820. Available online: https://www.indprop.gov.sk/swift_data/source/images/novinky/ 2018/01/EUIPO_Geographical_Indications_full_report_en.pdf?fbclid=IwAR0pqCAhYpx_plwaWEUZJDktuWAxJ_xviwGjS4 xeK_uSMQEFAImCcT_8iM8 (accessed on 16 April 2021).

18. Supeková, S.; Honza, M.; Kačenová, D. Perception of Slovak foodstuffs designated by protected geographical indication by Slovak consumers. J. Food Nutr. Res. 2008, 47, 205-208.

19. Official Journal of the European Union. Regulation (EU) No 1151/2012 of the European Parliament and of the Council of 21 November 2012 on quality schemes for agricultural products and foodstuffs. Off. J. Eur. Union 2012, 343, 1-29.

20. Michaeli, E.; Solár, V.; Vilček, J.; Ivanová, M. Selected Specific Foods and Agricultural Products with Protected Designation in Regions of The Slovak Republic as a Member State of The European Union. J. Int. Sci. Publ. Ecol. Saf. 2018, 12, 335-340.

21. European Commission. eAmbrosia-The EU Geographical Indications Register. 2020. Available online: https:/ / ec.europa.eu/ info/food-farming-fisheries/food-safety-and-quality/certification/quality-labels/geographical-indications-register/ (accessed on 6 November 2020).

22. Košičiarová, I.; Nagyová, L'.; Holienčinová, M.; Rybanská, J. Quality Label as the Guarantee of Higher Quality of Food-A Case Study of Slovak Food Market. Procedia Soc. Behav. Sci. 2016, 220, 200-209. [CrossRef]

23. Jad'ud'ová, J.; Badida, M.; Badidová, A.; Marková, I.; Ťahúňová, M.; Hroncová, E. Consumer behavior towards regional eco-labels in Slovakia. Sustainability 2020, 12, 5146. [CrossRef]

24. Jarossová, M.A. Sales promotion of Slovak food on the Slovak market. Nauk. Inżynierskie Technol. 2017, 4, 23-40.

25. Melichová, K.; Varecha, L. Endogenous Political, Institutional, Cultural, and Geographic Determinants of Intermunicipal Cooperation-Evidence from Slovakia. Sustainability 2020, 12, 709. [CrossRef]

26. Michalek, J.; Ciaian, P.; Pokrivcak, J. The impact of producer organizations on farm performance: The case study of large farms from Slovakia. Food Policy 2018, 75, 80-92. [CrossRef]

27. Ulman, M.; Šimek, P.; Masner, J.; Kogut, P.; Löytty, T.; Crehan, P.; Charvát, K.; Oliva, A.; Bergheim, S.; Kalaš, M.; et al. Towards Future Oriented Collaborative Policy Development for Rural Areas and People. AGRIS On-Line Pap. Econ. Inform. 2020, 12, 111-124. [CrossRef]

28. Workshop on Building the Vision from More Attractive Rural Areas-PoliRURAL. Available online: https://polirural.eu/2021/0 3/05/workshop-on-building-the-vision-from-more-attractive-rural-areas / (accessed on 10 January 2021).

29. Halama, P. Principles of Psychological Diagnosis; University of Trnava, Faculty of Philosophy: Tranava, Slovakia, 2011.

30. Cohen, J. Statistical Power Analysis for the Behavioral Sciences, 2nd ed.; Lawrence Erlbaum Associates: Hillsdale, NJ, USA, 1998. 